Research paper

\title{
Ammonium sorption by Gördes clinoptilolite rich mineral specimen
}

\author{
Beyhan Cansever Erdoğan *, Semra Ülkü \\ Chemical Engineering Department, Faculty of Engineering, Izmir Institute of Technology, Gulbahce Koyu, 35430 Urla, Izmir, Turkey
}

\section{A R T I C L E I N F O}

\section{Article history:}

Received 1 February 2011

Received in revised form 22 August 2011

Accepted 10 September 2011

Available online 10 October 2011

\section{Keywords:}

Clinoptilolite rich mineral specimen

Ammonium

Sorption kinetic model

Thermodynamic parameter

\begin{abstract}
A B S T R A C T
Experimental and theoretical works were performed for the estimation of the effects of $\mathrm{pH}$, initial concentration, agitation speed, particle size and temperature on the ammonium sorption by local clinoptilolite rich mineral specimen. The kinetic sorption data were analyzed using external mass transfer, intraparticle diffusion, pseudo first and second order kinetic models. Diffusion model results revealed that external film diffusion dominated at the very early stages of sorption process and then it was overcome by intraparticle diffusion. Pseudo-second order kinetic model correlated with the experimental data better than the pseudo first order kinetic model. Sorption isotherm model results indicated that the Langmuir isotherm fitted well to the experimental data. Thermodynamic parameters Gibbs energy change $(\Delta \mathrm{G})$, enthalpy change $(\Delta H)$ and entropy change $(\Delta S)$ were calculated. It was shown that the sorption process was exothermic and spontaneous. The value of the activation energy suggested that ammonium sorption by the clinoptilolite rich mineral specimen is likely due to physical interactions between the sorbent and the sorbate. Analysis of the cation exchange results revealed that ion exchange mechanism was not the only step which was effective in ammonium sorption.
\end{abstract}

(c) 2011 Elsevier B.V. All rights reserved.

\section{Introduction}

The excessive amount of ammonium in the environment leads to decrease in dissolved oxygen level and eutrophication problem which result in excessive algal growth and toxic effect on aquatic life. Methods for the ammonium removal are air stripping, biological nitrification-denitrification and breakpoint chlorination. However, due to the concerns related to high energy input and large amounts of secondary wastes produced, further research on alternative methods is needed. Sorption by natural and synthetic based sorbents has been widely used as an alternative method because of the high removal efficiencies of the sorbents and low-cost technology it offers. Of these sorbents, clinoptilolite rich mineral specimen has special value due to its low cost and abundancy in nature.

Clinoptilolite is a crystalline hydrated aluminosilicate with the framework structure composed of $\mathrm{AlO}_{4}$ and $\mathrm{SiO}_{4}$ tetrahedra, channels and cavities. The isomorphic substitution of $\mathrm{Si}^{4+}$ by $\mathrm{Al}^{3+}$ causes a negative charge which is compensated by exchangeable cations such as $\mathrm{Na}^{+}, \mathrm{K}^{+}, \mathrm{Ca}^{2+}$ and $\mathrm{Mg}^{2+}$. Due to its unique adsorption, cation exchange, catalytic, hydration and dehydration properties, clinoptilolite rich mineral specimen has been proposed for ammonium (Huang et al., 2010; Karapınar, 2009; Şenatalar and Sirkecioğlu, 1995; Ülkü, 1984) and heavy metal removal (Can et al., 2010; Motsi et al., 2009; Top and Ülkü, 2004), animal nutrition (Mumpton, 1999), gas

\footnotetext{
* Corresponding author. Tel.: +90 232 7506671; fax: +90232 7506645. E-mail address: beyhancansever@iyte.edu.tr (B.C. Erdoğan).
}

adsorption (Armenta et al., 2003; Faghihian et al., 2008; Özkan and Ülkü, 2005), building and polymer industry (Atakul et al., 2005; Demir et al., 2008; Erdoğan et al., 2008; Savrık et al., 2010), as well as for biomedical applications (Pavelic et al., 2001, 2002).

The main objective of this work is to investigate the effects of experimental parameters such as particle size, $\mathrm{pH}$, agitation speed, initial concentration and temperature on the ammonium sorption. Kinetic models were used to explain possible mechanism involved in the ammonium sorption process. Sorption equilibrium models and thermodynamic parameters were also evaluated.

\section{Materials and methods}

\subsection{Zeolite sample preparation}

Clinoptilolite rich mineral specimen, obtained from mineral deposits located in Manisa Gördes region, was grounded in a laboratory type ball-mill and classified into different particle size ranges. Then, the samples were wet sieved to remove soluble impurities. After wet sieving, they were dried overnight at $105{ }^{\circ} \mathrm{C}$ and then kept over saturated $\mathrm{NH}_{4} \mathrm{Cl}$ solution in a desiccator.

\subsection{Characterization of zeolite samples}

Crystalline species present in the natural rock were identified by Philips X'Pert Pro Diffractometer with Ni-filtered $\mathrm{CuK}_{\alpha}$ radiation in the range of $2 \theta$ values 5 to $50^{\circ}$. Crystalline morphology of the zeolite samples was investigated by Philips XL30S model Scanning Electron 
Microscope. FTIR characterizations were carried out between 400 and $4000 \mathrm{~cm}^{-1}$ by Shimadzu FTIR-8201 using $\mathrm{KBr}$ pellet technique. Thermogravimetric analyses of the mineral samples were performed by a thermal gravimetric analyzer (Shimadzu TGA-51, Shimadzu) up to $1000{ }^{\circ} \mathrm{C}$ at a heating rate of $10^{\circ} \mathrm{C} / \mathrm{min}$, under $40 \mathrm{ml} / \mathrm{min} \mathrm{N}_{2}$ flow. Chemical compositions of the samples were determined by Varian ICP-AES 96 Inductively Coupled Plasma Atomic Emission Spectrometer.

\subsection{Batch experiment}

Ammonium solution was prepared by dissolving $\mathrm{NH}_{4} \mathrm{Cl}$ (Sigma, 99.9\% pure) in deionized water. Solutions at different concentrations were obtained by diluting the stock solution with deionized water. The batch experiments were carried out in $250 \mathrm{~mL}$ cylindrical flask placed in a constant temperature water bath. Solid to solution ratio was used as 1:100 and this value was kept as constant in all the sorption experiments.

The effect of initial concentration of ammonium was examined by studying different initial concentrations changing from 10 to $300 \mathrm{mg} / \mathrm{L}$. In order to find out the effect of agitation speed, a series of experiments was carried out by varying the speed of agitation from 70 to $170 \mathrm{rpm}$. Three different particle size ranges (2-2.8, 20.85 and $0.85-0.60 \mathrm{~mm}$ ), three different $\mathrm{pH}$ values (4, 7 and 10 ) and two temperature values $\left(25\right.$ and $40{ }^{\circ} \mathrm{C}$ ) were studied.

Ammonium concentration was determined by using Ammonia Selective Electrode. Direct and standard addition methods were used to check the effect of interference on the selective electrode system.

The amount of ammonium sorbed by the clinoptilolite rich mineral specimen was calculated from the mass balance:

$\mathrm{q}(\mathrm{t})=\frac{\left(\mathrm{C}_{0}-\mathrm{C}_{\mathrm{t}}\right) \mathrm{V}}{\mathrm{m}}$

where $C_{0}$ is the initial concentration of ammonium in the solution $(\mathrm{mg} / \mathrm{L})$, $\mathrm{C}_{\mathrm{t}}$ is concentration of ammonium in the solution at time $\mathrm{t}(\mathrm{mg} / \mathrm{L}), \mathrm{V}$ is the volume of the solution (L), and $\mathrm{m}$ is the mass of the clinoptilolite rich mineral specimen $(\mathrm{g})$.

\section{Results and discussion}

\subsection{Characterization}

Representative SEM micrograph of mineral specimen used is presented in Fig. 1. Thin platy crystals which resemble to the clinoptilolite crystals were observed in the micrograph.

XRD patterns of the mineral specimen are given in Fig. 2. The mineral was confirmed to contain clinoptilolite as its characteristic peaks are recognized at $2 \theta=9.76^{\circ}, 22.23^{\circ}$ and $30.05^{\circ}$. Qualitative mineralogical analysis was performed by using search match program of Philips X'pert Pro X-ray diffractometer. The results revealed that clay (halloysite) and

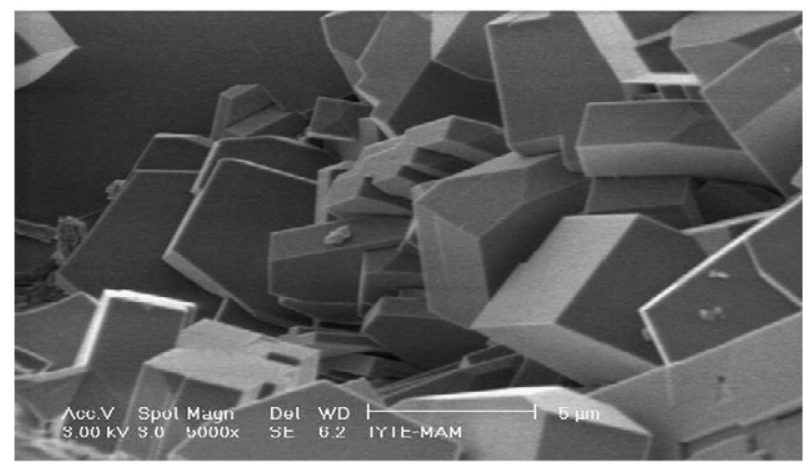

Fig. 1. SEM micrograph of clinoptilolite rich mineral specimen.

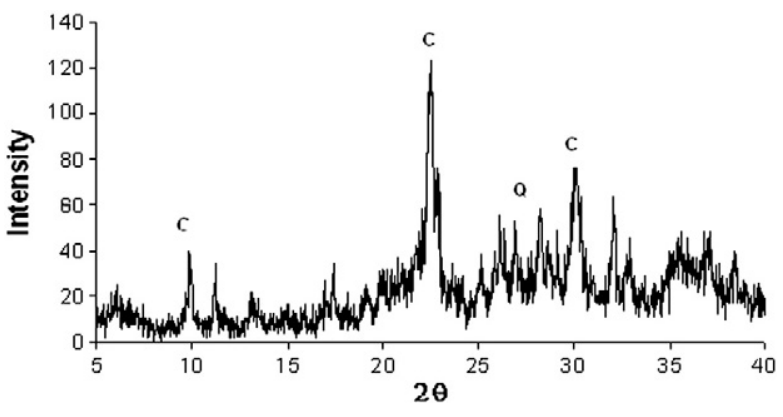

Fig. 2. XRD patterns of clinoptilolite rich mineral specimen.

quartz were the other major constituents of the clinoptilolite rich mineral specimen. Clinoptilolite content of the specimen was determined as $64 \%$ (Can et al., 2010) using relative intensity ratio (RIR) method (Chipera and Bish, 1995).

FTIR result of the clinoptilolite rich mineral specimen is shown in Fig. 3. Bands due to $\mathrm{T}-\mathrm{O}$ bending and $\mathrm{T}-\mathrm{O}$ stretching mode were observed at 474 and $1064 \mathrm{~cm}^{-1}$, respectively. Bands due to the presence of water were observed at $1600-3700 \mathrm{~cm}^{-1}$. Bands related to isolated $\mathrm{OH}$ stretching at $3651 \mathrm{~cm}^{-1}$, hydrogen bonding of water at $3471 \mathrm{~cm}^{-1}$ and water bending at $1658 \mathrm{~cm}^{-1}$ were seen.

Water content of clinoptilolite rich mineral sample was determined using TGA method with a procedure outlined by Knowlton and White (1981). The weight losses due to the external, loosely bound and tightly bound water were observed in the temperature ranges of $25-85^{\circ} \mathrm{C}, 85-285^{\circ} \mathrm{C}$ and $285-1000{ }^{\circ} \mathrm{C}$, respectively. External, loosely and tightly bound water content in the clinoptilolite rich mineral specimen were found as $4.2,5.5$ and $2.4 \%$, respectively. DTA results of the specimen showed that the structure of the sample collapsed around $900{ }^{\circ} \mathrm{C}$.

Chemical composition of the specimen is given in Table 1. Accordingly, the sample was identified as potassium clinoptilolite rich mineral specimen due to its high potassium content. $\mathrm{SiO}_{2} / \mathrm{Al}_{2} \mathrm{O}_{3}$ ratio (wt.\%) of the sample was found as 5.1. Cation exchange capacity of the Gördes clinoptilolite was calculated from the summation of the exchangeable cations and determined as $2.41 \mathrm{meq} / \mathrm{g}$. Particle density and porosity were found as $1.8 \mathrm{~g} / \mathrm{cm}^{3}$ and 0.33 , respectively.

\subsection{Effect of experimental parameters on ammonium sorption}

\subsubsection{Effect of initial ammonium concentration}

The effect of initial ammonium concentration is shown in Fig. 4. The trend for each initial concentration was observed to be similar. Basically, the initial uptake rate was rapid at the beginning of the sorption process due to the availability of large number of unoccupied sites in the sorbent. As contact time progressed, initial uptake rate gradually slowed down as the sorption sites in the sorbent were occupied and fewer available sites were involved in the sorption process. At equilibrium, the uptake rate approached to zero as expected.

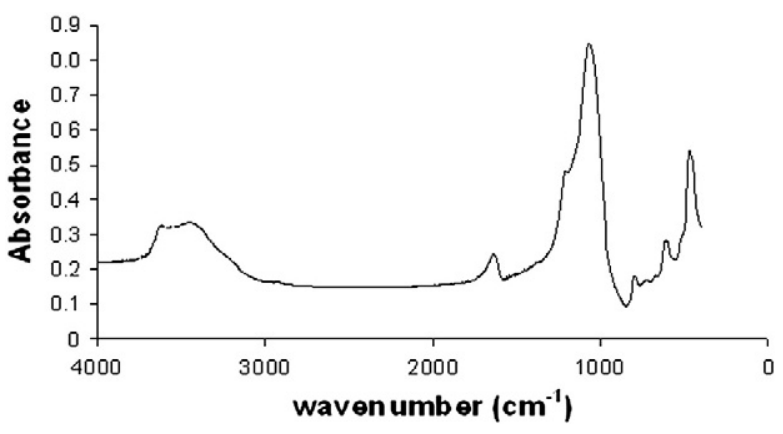

Fig. 3. FTIR spectra of clinoptilolite rich mineral specimen. 
Table 1

Chemical composition of Gördes clinoptilolite rich mineral specimen (oxide wt.\%).

\begin{tabular}{lc}
\hline Composition & Weight (\%) \\
\hline $\mathrm{SiO}_{2}$ & 65.19 \\
$\mathrm{Al}_{2} \mathrm{O}_{3}$ & 12.93 \\
$\mathrm{Fe}_{2} \mathrm{O}_{3}$ & 1.45 \\
$\mathrm{Na}_{2} \mathrm{O}$ & 0.92 \\
$\mathrm{~K}_{2} \mathrm{O}$ & 3.99 \\
$\mathrm{CaO}$ & 1.99 \\
$\mathrm{MgO}$ & 1.39 \\
$\mathrm{H}_{2} \mathrm{O}$ & 12.1 \\
\hline
\end{tabular}

Fig. 4 also showed that at equilibrium the amount of ammonium sorbed by the clinoptilolite rich mineral specimen increased with increasing initial ammonium concentration which indicates the gradual steps to saturation of the sorbent with the ammonium molecules. Initial ammonium uptake rate was observed to increase with increasing ammonium concentration, as expected, since the concentration difference between the solute phase and sorbent phase is the driving force for the sorption process.

\subsubsection{Effect of agitation speed}

The effects of the agitation speed on the initial uptake rate and on the amount of ammonium sorbed were investigated by changing the speed from 70 to $170 \mathrm{rpm}$ and the results are shown in Fig. 5. It is well known that the agitation speed influences the formation of the external film boundary layer. By increasing the agitation speed, the external mass resistance becomes smaller due to the reduction of the thickness of the boundary layer. As seen in the figure, initial uptake rate increased with increasing agitation speed. The results also indicated that at equilibrium the amount of ammonium sorbed by the clinoptilolite rich mineral specimen remained constant as the agitation speed increased. This may suggest that external mass transfer resistance is likely to have more significant effect at the early stages of the sorption process.

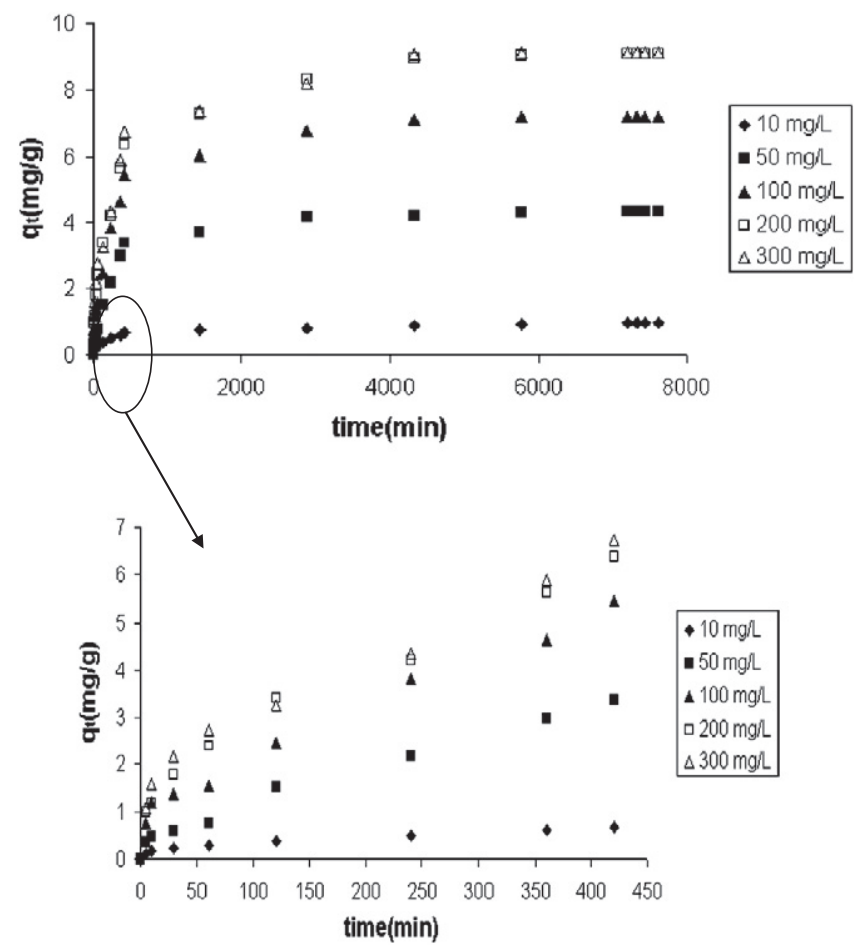

Fig. 4. Effect of initial concentration on ammonium sorption by clinoptilolite rich mineral specimen (experimental conditions: agitation speed $=170 \mathrm{rpm}, \mathrm{pH}=7.0$, particle size: 2 $\left.0.85 \mathrm{~mm}, \mathrm{~T}=25^{\circ} \mathrm{C}\right)$

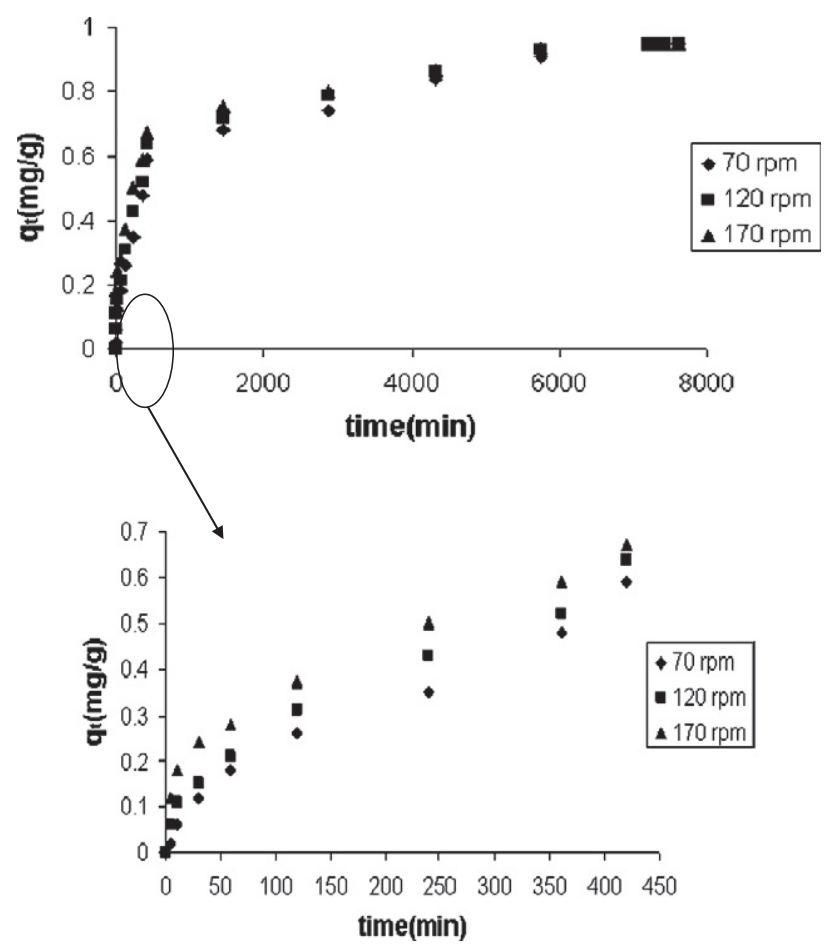

Fig. 5. Effect of agitation speed on ammonium sorption by clinoptilolite rich mineral specimen (experimental conditions: particle size $=2-0.85 \mathrm{~mm}, \mathrm{pH}=7.0$, initial concentration $=10 \mathrm{mg} / \mathrm{L}, \mathrm{T}=25^{\circ} \mathrm{C}$ ).

\subsubsection{Effect of particle size}

Fig. 6 shows the effect of particle size on the ammonium sorption. The figure clearly indicates that higher initial uptake rate was obtained with smaller particles, but at equilibrium amount of ammonium sorbed by the clinoptilolite rich mineral specimen did not change with the change in the particle size.

It is well known that total surface area of the porous material is composed of external and internal surface areas which cover pores and channels of the material. When the particle size of the material

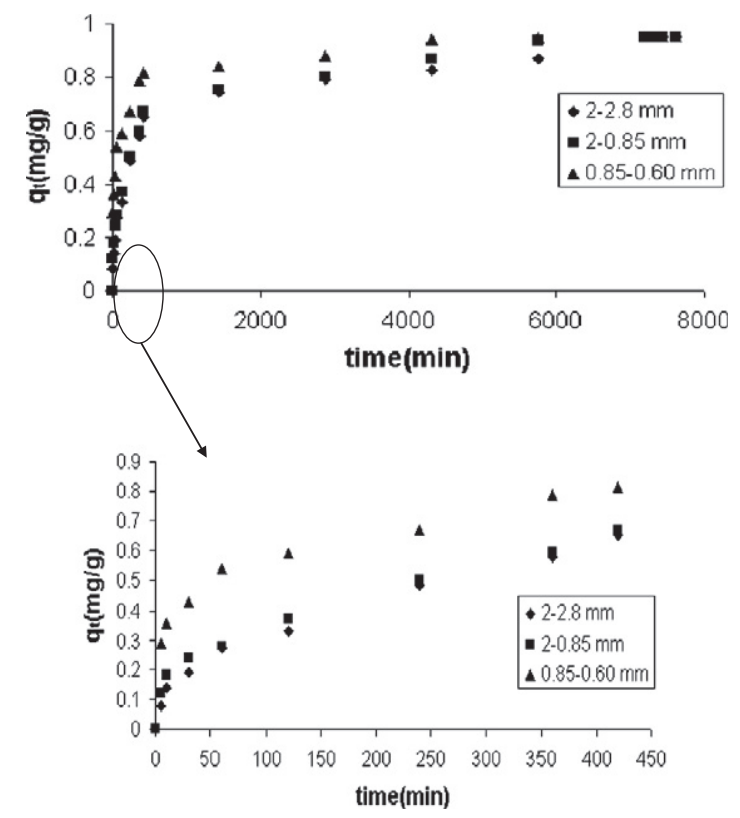

Fig. 6. Effect of particle size on ammonium sorption by clinoptilolite rich mineral specimen (experimental conditions: agitation speed $=170 \mathrm{rpm}, \mathrm{pH}=7.0$, initial concentration $=10 \mathrm{mg} / \mathrm{L}, \mathrm{T}=25^{\circ} \mathrm{C}$ ). 
is reduced, only external surface area increases; internal surface area is not affected considerably except some minor change due to opening of the clogged pores.

As the particle size decreased, initially a larger external surface area was exposed to solute molecules and thus initial uptake rate increased but later, with the saturation of active sites internal part became more effective as expected.

\subsubsection{Effect of temperature}

The effect of temperature on the ammonium sorption is shown in Fig. 7. It was observed that both the initial uptake rate and the amount of ammonium sorbed at equilibrium decreased with increasing temperature. The decrease in the amount of ammonium sorbed with increasing temperature indicated that there exists a weak interaction between ammonium and clinoptilolite rich mineral specimens; this supports physical sorption process Moreover, the decrease in the ammonium sorption with increasing temperature revealed that ammonium sorption was an exothermic process and thus it was favored at low temperature.

\subsubsection{Effect of $\mathrm{pH}$}

The effects of $\mathrm{pH}$ on the initial uptake rate and on the amount of ammonium sorbed were investigated and the results are shown in Fig. 8. Initial uptake rate and the amount of ammonium sorbed at equilibrium at $\mathrm{pH} 4$ and 10 were observed to be lower than those at $\mathrm{pH}$ 7. This can be attributed to the different ammonium species and ionization products of the water at different $\mathrm{pH}$ values. Ammonium exists in the aqueous solution in the form of $\mathrm{NH}_{3}$ (ammonia) and $\mathrm{NH}_{4}^{+}$(ammonium) depending on the $\mathrm{pH}$ of the solution and the temperature. In the $\mathrm{pH}$ range of 1 to $5 \mathrm{NH}_{4}^{+}$is the principal one; while in the $\mathrm{pH}$ range of 8 to $14 \mathrm{NH}_{3}$ is the dominant form in the solution. Compared to neutral ammonia molecules, positively charged ammonium ions are more likely to interact with the negatively charged clinoptilolite. Thus, at high $\mathrm{pH}$ values at which the population of ammonia species increases, a reduction in the uptake is not exceptional. At acidic $\mathrm{pH}$ case, on the other hand, though ammonium is dominating species,

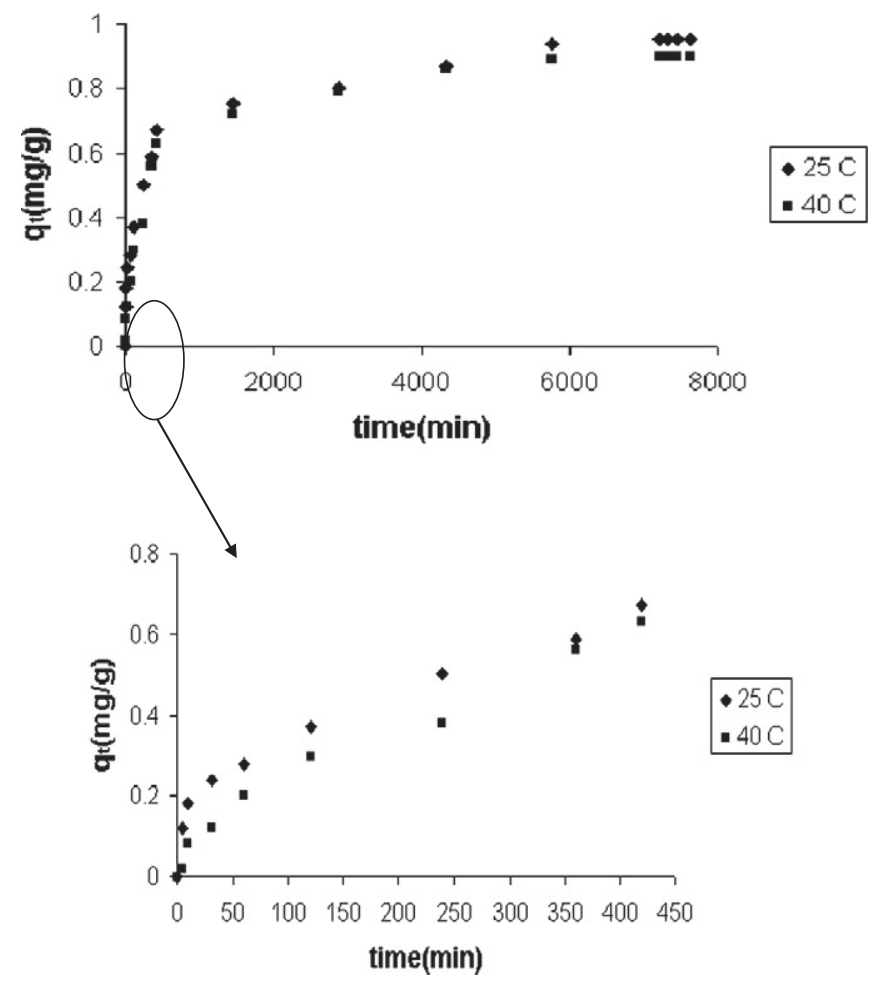

Fig. 7. Effect of temperature on ammonium sorption by clinoptilolite rich mineral specimen (experimental conditions: particle size $=2-0.85 \mathrm{~mm}, \mathrm{pH}=7.0$, initial concentration $=10 \mathrm{mg} / \mathrm{L}$, agitation speed $=170 \mathrm{rpm}$ ).

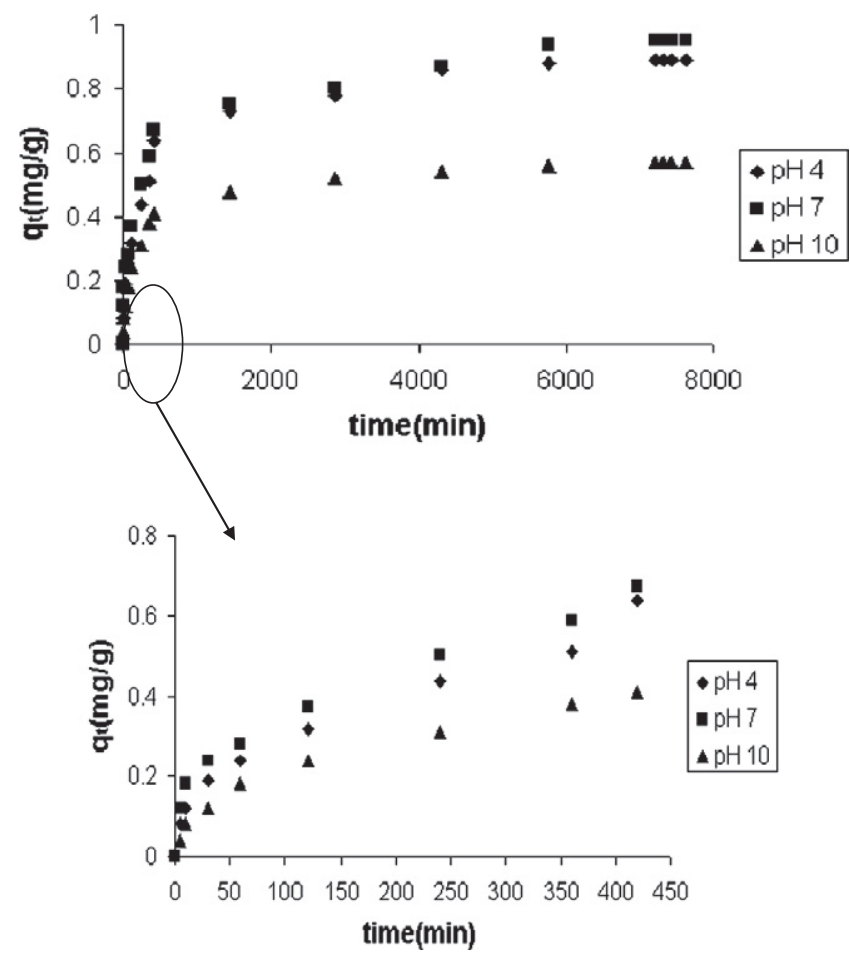

Fig. 8. Effect of pH on ammonium sorption by clinoptilolite rich mineral specimen (experimental conditions: agitation speed $=170 \mathrm{rpm}$, initial concentration $=10 \mathrm{mg} / \mathrm{L}$, particle size $=2-0.85 \mathrm{~mm}, \mathrm{~T}=25^{\circ} \mathrm{C}$ ).

the competition between hydrogen and ammonium ions lowers the ammonium uptake.

\subsection{Sorption kinetic models}

There are essentially four consecutive steps in the sorption process. In step 1, the solute is transported from the bulk solution to the external layer of the sorbent. Step 1 is non-limiting when agitation is sufficient to avoid concentration gradients in the solution. Step 2 involves diffusion of the solute across the external film surrounding the particle. The third step is composed of pore and surface diffusion. Pore diffusion is involved in the diffusion of the solute in the pores whereas surface diffusion arises due to the diffusion along the sorbent surface. Step 4 is involved in the sorption of the solute on the sorbent surface with surface reaction due to physical or chemical interaction. Physical sorption includes van der Walls forces, electrostatic interactions, $\Pi-\Pi$ and hydrogen bonding forces whereas chemical sorption covers sorption forces through sharing or exchange of electrons between sorbate and sorbent (ion exchange). If ion exchange is involved in the sorption step, the diffusion of the released exchangeable cations is also effective in the sorption process and thus sorption mechanism becomes more complicated. Sorption rate is significantly influenced by the type and the concentration of these cations.

The rate limiting step is resulted from one of these step or combination of them. In order to decide which step is the rate limiting one, experimental parameters such as agitation speed, particle size, initial concentration, $\mathrm{pH}$ and temperature should be comprehensively discussed and analysis of the kinetic models should be performed considering them.

\subsubsection{External mass transfer coefficient $\left(k_{f}\right)$}

External film diffusion occurs by molecular diffusion through the laminar boundary layer. The thickness of the boundary layer affects the external mass transfer resistance which depends on the hydrodynamic conditions of the fluid. External mass transfer resistance is 
correlated in terms of a mass transfer coefficient $\left(\mathrm{k}_{\mathrm{f}}\right)$. An increase in the $\mathrm{k}_{\mathrm{f}}$ value indicates a decrease in the external mass transfer resistance.

External Mass Transfer Coefficient $\left(\mathrm{k}_{\mathrm{f}}\right)$ was determined by Mathew-Weber Model (Mathews and Weber, 1976) which assumes that only external film diffusion is dominant during the initial sorption period and controls the sorption process. The model equation is given in Eq. (2).

$\ln \frac{\mathrm{C}_{\mathrm{t}}}{\mathrm{C}_{0}}=-\mathrm{k}_{\mathrm{f}} \mathrm{St}$

where $C_{t}$ is the concentration of ammonium ion in the solution at time $t(\mathrm{mg} / \mathrm{L}), \mathrm{C}_{0}$ is the initial concentration of ammonium ion in the solution $(\mathrm{mg} / \mathrm{L}), \mathrm{S}$ is the surface area for mass transfer $\left(\mathrm{m}^{-1}\right), \mathrm{k}_{\mathrm{f}}$ is the external mass transfer coefficient $(\mathrm{m} / \mathrm{s})$, and $\mathrm{t}$ is the time $(\mathrm{s})$.

$S=\frac{6 m / V}{d_{p} \rho_{p}\left(1-\varepsilon_{p}\right)}$

$m$ is the mass of sorbent $(g), V$ is the volume of solution $(L), d_{p}$ is the particle diameter $(\mathrm{m}), \rho_{\mathrm{p}}$ is the particle density $(\mathrm{g} / \mathrm{L})$ and $\varepsilon_{\mathrm{p}}$ is the porosity of the particle.

The initial slope of the linear plot of $\ln C_{t} / C_{0}$ versus $t$ was used in the determination of external mass transfer coefficient $\left(\mathrm{k}_{\mathrm{f}}\right)$. Calculated external mass transfer coefficients are listed in Table 2 . The values of the coefficients are in the order of $10^{-6}$. The results indicated that the external mass transfer coefficient decreased with increasing initial concentration and temperature whereas it increased with increasing particle size and agitation speed. An increase in the initial concentration caused an increase in the external mass transfer resistance. The pore over filling due to the release of the exchanged cations and increase in skin resistance might have been cause of the increase in the external mass transfer resistance. As the particle size decreased, the external mass transfer effect on the sorption rate became significant. Increasing agitation speed caused to decrease in the thickness of the boundary layer resistance surrounding the particle and thus external mass transfer resistance decreased with increasing agitation speed. The results implied that the effect of $\mathrm{pH}$ on the external mass transfer coefficient $\left(\mathrm{k}_{\mathrm{f}}\right)$ was irregular. An increase in temperature caused to slight increase in the external mass transfer resistance.

Using the external mass transfer coefficient obtained from Mathew and Weber Model, the comparison of theoretical and experimental decay curves for two different initial concentrations are shown in Fig. 9. Although they almost overlapped for the first

Table 2

The values of external mass transfer coefficients at different conditions.

\begin{tabular}{llcl}
\hline Parameters & & $\mathrm{k}_{\mathrm{f}} * 10^{6}(\mathrm{~m} / \mathrm{s})$ & $\mathrm{R}^{2}$ \\
\hline Initial concentration $(\mathrm{mg} / \mathrm{L})$ & 10 & 8.6 & 0.98 \\
& 50 & 5.7 & 0.95 \\
& 100 & 5.2 & 0.98 \\
& 200 & 2.9 & 0.87 \\
& 300 & 2.6 & 0.96 \\
Particle size $(\mathrm{mm})$ & $2-2.8$ & 14.3 & 0.99 \\
& $2-0.85$ & 8.6 & 0.98 \\
Agitation speed $(\mathrm{rpm})$ & $0.85-0.6$ & 7.3 & 0.92 \\
& 70 & 2.9 & 0.96 \\
& 120 & 5.7 & 0.99 \\
Temperature $\left({ }^{\circ} \mathrm{C}\right)$ & 170 & 8.6 & 0.98 \\
& 25 & 8.6 & 0.98 \\
$\mathrm{pH}$ & 40 & 2.9 & 0.92 \\
& 4 & 5.7 & 0.94 \\
& 7 & 8.6 & 0.98 \\
& 10 & 2.9 & 0.92
\end{tabular}
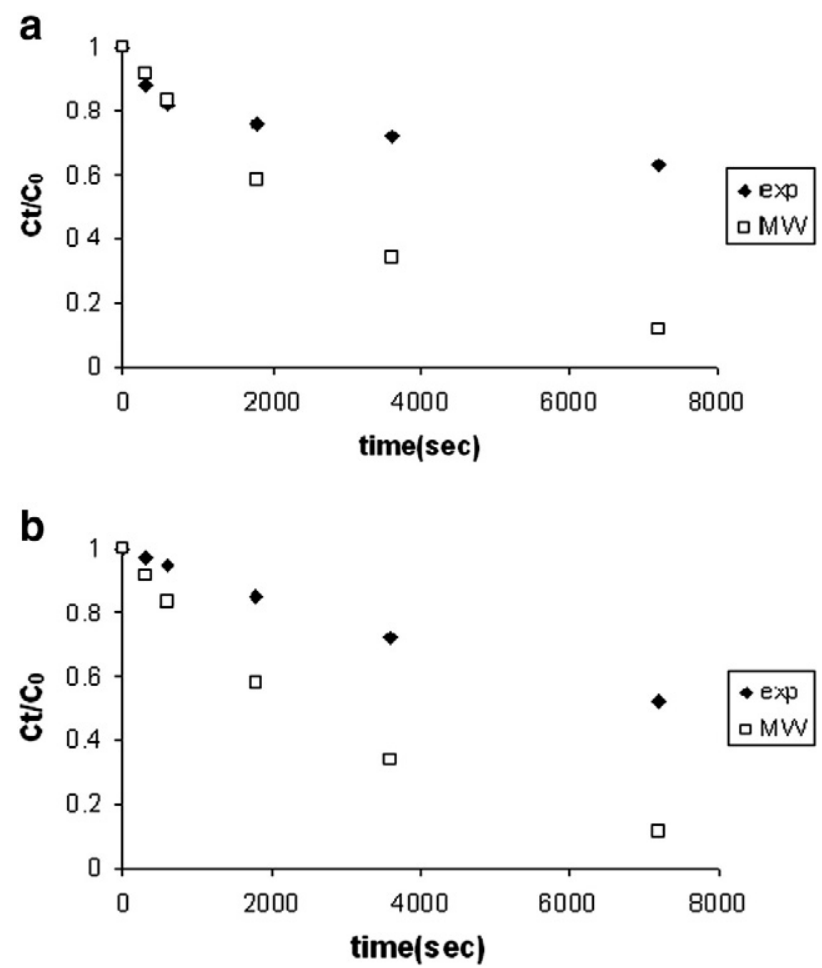

Fig. 9. Comparison of theoretical and experimental concentration decay curves at two different initial concentrations conditions a) $10 \mathrm{mg} / \mathrm{L}$ and b) $300 \mathrm{mg} / \mathrm{L}$ (experimental conditions: agitation speed $=170 \mathrm{rpm}$, particle size $=2-0.85 \mathrm{~mm}, \mathrm{~T}=25^{\circ} \mathrm{C}, \mathrm{pH}=7$ ).

10 min of the experiment, thereafter noticeable deviation was observed between the experimental and theoretical data; this indicates involvement of other mass transfer resistances. In order to assess the contribution of them, further analysis needed.

\subsubsection{Intraparticle diffusion rate constant $\left(k_{d}\right)$}

Weber-Morris model, which had been derived from the Fick's second law assuming the effect of the external mass transfer resistance as negligible, the direction of diffusion as radial and no change in the concentration in the angular direction and the intraparticle diffusivity as constant (Malash and El-Khaiary, 2010; Weber and Morris, 1963), was used to calculate intraparticle diffusion rate constant. The model equation is given below:

$\mathrm{q}_{\mathrm{t}}=\mathrm{k}_{\mathrm{d}} \mathrm{t}^{1 / 2}$

where $\mathrm{q}_{\mathrm{t}}$ is the amount of ammonium sorbed at time $\mathrm{t}(\mathrm{mg} / \mathrm{gr}), \mathrm{k}_{\mathrm{d}}$ is the intraparticle diffusion rate constant $\left(\mathrm{mg} / \mathrm{gr} \mathrm{min}^{0.5}\right)$ and $\mathrm{t}^{0.5}$ is the time $\left(\min ^{0.5}\right)$

Intraparticle diffusion rate constant was calculated from the slope of the plots of $\mathrm{q}_{\mathrm{t}}$ versus $\mathrm{t}^{1 / 2}$. The plots of $\mathrm{q}_{\mathrm{t}}$ versus $\mathrm{t}^{1 / 2}$ for ammonium sorption by clinoptilolite rich mineral specimens at 10 and $300 \mathrm{mg} / \mathrm{L}$ are shown in Fig. 10. It is evident from the figure that, the plots shows multilinearity and do not pass through the origin. According to Weber and Morris (1963), if the rate-limiting step is intraparticle diffusion, a plot of $\mathrm{q}_{\mathrm{t}}$ versus $\mathrm{t}^{1 / 2}$ should yield a straight line passing through the origin. If the plot $\mathrm{q}_{t}$ versus $\mathrm{t}^{1 / 2}$ shows multi linearity, more than one step is involved in the sorption process. The multilinearity coming from four linear segments in these plots indicates that more than one step is effective in the sorption process and the intraparticle diffusion is not the sole rate limiting one; this is also indicated by the other investigators. Allen et al. (1989) explains the multi-linearity of the plots by the external mass transfer; and the intraparticle diffusion regions. Walker et al. (2003) states four regions; the initial stage representing external mass transfer, with the 

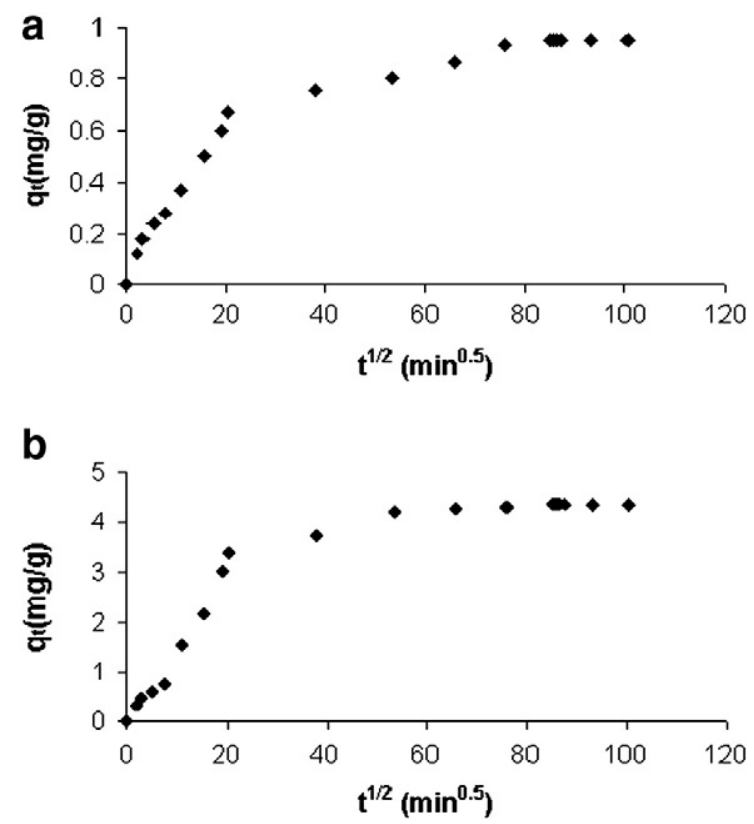

Fig. 10. Plots of $q_{t}$ versus $t^{1 / 2}$ for the ammonium sorption by clinoptilolite rich mineral specimen at a) $10 \mathrm{mg} / \mathrm{L}$ and b) $300 \mathrm{mg} / \mathrm{L}$ (experimental conditions: agitation speed $=170 \mathrm{rpm}$, particle size $=2-0.85 \mathrm{~mm}, \mathrm{~T}=25^{\circ} \mathrm{C}, \mathrm{pH}=7$ ).

following three stages representing intra-particle diffusion in the macro, meso and micropore structure of the sorbent.

Intraparticle diffusion rate constants are tabulated in Table 3. The intraparticle diffusion rate constant increased with increasing initial concentration. The increase in the initial concentration resulted in an increase in the driving force and thus diffusion rate of ammonium into the pores increased. Increasing agitation speed resulted in a slight reduction of value the of the intraparticle diffusion rate constant. Although there is a decrease in the external resistance and increase in the initial uptake rate with agitation speed, this reduction may be attributed to the pore over filling due to concentration increase of the released exchangeable cations. The pore blocking due to the competition between solute molecules for available sorption sites may also be effective. The results also implied that the effect of $\mathrm{pH}$ on the intraparticle diffusion rate constant $\left(\mathrm{k}_{\mathrm{d}}\right)$ was irregular. As the particle size increased, the distance for diffusion of solute molecule in the particle becomes longer and it takes more time to diffuse to the interior of the particle. Increasing particle size yielded higher intraparticle diffusion resistance. Increasing temperature resulted in slight increase in intraparticle diffusion rate constant.

Table 3

The values of intraparticle diffusion rate constant at different conditions.

\begin{tabular}{llcl}
\hline Parameters & & $\mathrm{k}_{\mathrm{d}} * 10^{3}\left(\mathrm{mg} / \mathrm{gr} \mathrm{min}{ }^{0.5}\right)$ & $\mathrm{R}^{2}$ \\
\hline Initial concentration $(\mathrm{mg} / \mathrm{L})$ & 10 & 4.8 & 0.97 \\
& 50 & 17.4 & 0.94 \\
& 100 & 33.3 & 0.97 \\
& 200 & 61.0 & 0.99 \\
& 300 & 61.5 & 0.99 \\
Particle size $(\mathrm{mm})$ & $2-2.8$ & 3.2 & 0.98 \\
& $2-0.85$ & 4.8 & 0.97 \\
Agitation speed $(\mathrm{rpm})$ & $0.85-0.6$ & 5.2 & 0.98 \\
& 70 & 6.2 & 0.98 \\
& 120 & 5.5 & 0.97 \\
Temperature $\left({ }^{\circ} \mathrm{C}\right)$ & 170 & 4.8 & 0.99 \\
& 25 & 4.8 & 0.97 \\
$\mathrm{pH}$ & 40 & 5.4 & 0.98 \\
& 4 & 4.6 & 0.96 \\
& 7 & 4.8 & 0.97 \\
& 10 & 2.2 & 0.98
\end{tabular}

3.3.3. Pseudo first and second order $\left(k_{1}\right.$ and $\left.k_{2}\right)$ model

After integration and applying boundary conditions $(\mathrm{t}=0$ to $\mathrm{t}=\mathrm{t}$ and $\mathrm{q}_{\mathrm{t}}=0$ to $\mathrm{q}_{\mathrm{t}}=\mathrm{q}_{\mathrm{t}}$ ) to pseudo first order equation: (Lagergren, 1898)

$\frac{\mathrm{dq}_{\mathrm{t}}}{\mathrm{dt}}=\mathrm{k}_{1}\left(\mathrm{q}_{\mathrm{e}}-\mathrm{q}_{\mathrm{t}}\right)$

the integrated form of Eq. (5) becomes:

$\log \left(\mathrm{q}_{\mathrm{e}}-\mathrm{q}_{\mathrm{t}}\right)=\log \mathrm{q}_{\mathrm{e}}-\frac{\mathrm{k}_{1}}{2.303} \mathrm{t}$

where $\mathrm{q}_{\mathrm{e}}$ and $\mathrm{q}_{\mathrm{t}}$ are the amount of ammonium sorbed at equilibrium and at time $t(\mathrm{mg} / \mathrm{g}), \mathrm{k}_{1}$ is the pseudo first order rate constant $(1 / \mathrm{min})$ and $\mathrm{t}$ is the time(min).

The first-order rate constant $\mathrm{k}\left(\mathrm{min}^{-1}\right)$ and calculated $\mathrm{q}_{\mathrm{e}}$ values were determined from the slope and intercept of the $\log \left(\mathrm{q}_{\mathrm{e}}-\mathrm{q}_{\mathrm{t}}\right)$ versus t plot.

Differential form of the pseudo second-order sorption kinetic equation is expressed by Eq. (7). (Ho and McKay, 2000)

$\frac{\mathrm{dq}_{\mathrm{t}}}{\mathrm{dt}}=\mathrm{k}_{2}\left(\mathrm{q}_{\mathrm{e}}-\mathrm{q}_{\mathrm{t}}\right)^{2}$

where $\mathrm{q}_{\mathrm{e}}$ and $\mathrm{q}_{\mathrm{t}}$ are the amount of ammonium sorbed at equilibrium and at time $\mathrm{t}(\mathrm{mg} / \mathrm{g}), \mathrm{k}_{2}$ is the pseudo second-order rate constant $\left(\mathrm{g} \mathrm{mg}^{-1} \mathrm{~min}^{-1}\right.$ ) and $\mathrm{t}$ is the time (min).

After integration and applying boundary conditions $\mathrm{t}=0$ to $\mathrm{t}=\mathrm{t}$ and $\mathrm{q}_{\mathrm{t}}=0$ to $\mathrm{q}_{\mathrm{t}}=\mathrm{q}_{\mathrm{t}}$, Eq. ( 7 ) becomes:

$\frac{1}{q_{e}-q_{t}}=\frac{1}{q_{e}}+k_{2} t$

Eq. (8) can be rearranged to obtain Eq. (9).

$\left(\frac{\mathrm{t}}{\mathrm{q}_{\mathrm{t}}}\right)=\frac{1}{\mathrm{k}_{2} \mathrm{q}_{\mathrm{e}}^{2}}+\frac{1}{\mathrm{q}_{\mathrm{e}}}(\mathrm{t})$.

The second-order rate constant $\left(\mathrm{k}_{2}\right)$ and calculated $\mathrm{q}_{\mathrm{e}}$ values were determined from the slopes and the intercepts of the plot of $t / q_{t}$ versus t. The pseudo first and second order model rate constants, model correlation coefficients and calculated $\mathrm{q}_{\mathrm{e}}$ values are tabulated in Tables 4 and 5 . The results indicated that pseudo first order rate constant $\left(\mathrm{k}_{1}\right)$ decreased with increasing initial concentration, particle size, temperature whereas it increased with increasing agitation speed. The values of pseudo second order rate constant $\left(k_{2}\right)$ decreased with increasing initial concentration, temperature and particle size whereas it increased with increasing $\mathrm{pH}$ and agitation

Table 4

The values pseudo first order rate constant at different conditions.

\begin{tabular}{lllll}
\hline Parameters & & $\mathrm{k}_{1} * 10^{3}\left(\mathrm{~min}^{-1}\right)$ & $\mathrm{q}_{\mathrm{e}(\mathrm{cal})}(\mathrm{mg} / \mathrm{g})$ & $\mathrm{R}^{2}$ \\
\hline Initial concentration $(\mathrm{mg} / \mathrm{L})$ & 10 & 8.3 & 0.89 & 0.80 \\
& 50 & 7.8 & 4.17 & 0.70 \\
& 100 & 6.2 & 6.9 & 0.68 \\
& 200 & 6 & 8.7 & 0.82 \\
& 300 & 4 & 8.7 & 0.81 \\
Particle size $(\mathrm{mm})$ & $2-2.8$ & 6.7 & 0.91 & 0.83 \\
& $2-0.85$ & 8.3 & 0.89 & 0.80 \\
Agitation speed $(\mathrm{rpm})$ & $0.85-0.6$ & 16.4 & 0.80 & 0.7 \\
& 70 & 4.4 & 0.95 & 0.97 \\
Temperature $\left({ }^{\circ} \mathrm{C}\right)$ & 120 & 5.1 & 0.92 & 0.83 \\
& 170 & 8.3 & 0.89 & 0.80 \\
$\mathrm{pH}$ & 25 & 8.3 & 0.89 & 0.80 \\
& 40 & 4.6 & 0.89 & 0.88 \\
& 4 & 7.1 & 0.86 & 0.90 \\
& 7 & 8.3 & 0.89 & 0.80 \\
& 10 & 7.4 & 0.55 & 0.90 \\
\hline
\end{tabular}


Table 5

The values pseudo second order rate constant at different conditions.

\begin{tabular}{lllll}
\hline Parameters & & $\begin{array}{l}\mathrm{k}_{2}^{*} 10^{3} \\
(\mathrm{gr} / \mathrm{mg} \mathrm{min})\end{array}$ & $\begin{array}{l}\mathrm{qe}(\mathrm{cal}) \\
(\mathrm{mg} / \mathrm{g})\end{array}$ & $\mathrm{R}^{2}$ \\
\hline Initial concentration $(\mathrm{mg} / \mathrm{L})$ & 10 & 5.7 & 0.95 & 0.996 \\
& 50 & 1.2 & 4.34 & 0.999 \\
& 100 & 0.8 & 7.17 & 0.999 \\
& 200 & 0.60 & 9.05 & 0.998 \\
Particle size $(\mathrm{mm})$ & 300 & 0.6 & 9.13 & 0.998 \\
& $2-2.8$ & 4.8 & 0.94 & 0.998 \\
Agitation speed $(\mathrm{rpm})$ & $2-0.85$ & 5.7 & 0.95 & 0.996 \\
& $0.85-0.6$ & 13.5 & 0.95 & 0.999 \\
& 70 & 3.1 & 0.95 & 0.996 \\
Temperature $\left({ }^{\circ} \mathrm{C}\right)$ & 120 & 4.2 & 0.95 & 0.993 \\
& 170 & 5.7 & 0.95 & 0.996 \\
$\mathrm{pH}$ & 25 & 5.7 & 0.95 & 0.996 \\
& 40 & 4.5 & 0.9 & 0.99 \\
& 4 & 5.6 & 0.89 & 0.998 \\
& 7 & 5.7 & 0.95 & 0.996 \\
& 10 & 10.8 & 0.57 & 0.999 \\
\hline
\end{tabular}

speed. The correlation coefficients of the pseudo first order model at different experimental parameters are lower than 0.90 (with one exception obtained for the lowest agitation speed) indicate that the pseudo first order model is not likely to describe the sorption model. On the other hand, the correlation coefficient values of the pseudo second order model $\left(R^{2}\right)$ are quite close to unity $(>0.99)$ and calculated $\mathrm{q}_{\mathrm{e}}$ values are very close to the experimental $\mathrm{q}_{\mathrm{e}}$ values.

Fig. 11 shows a comparison of the pseudo-first and second order kinetic models and the experimental results. As it is seen from the figure that, pseudo second order model was fitted well to experimental data. The pseudo first and second order model results indicated that the ammonium sorption by clinoptilolite rich mineral specimen can be well described by the pseudo second order model.
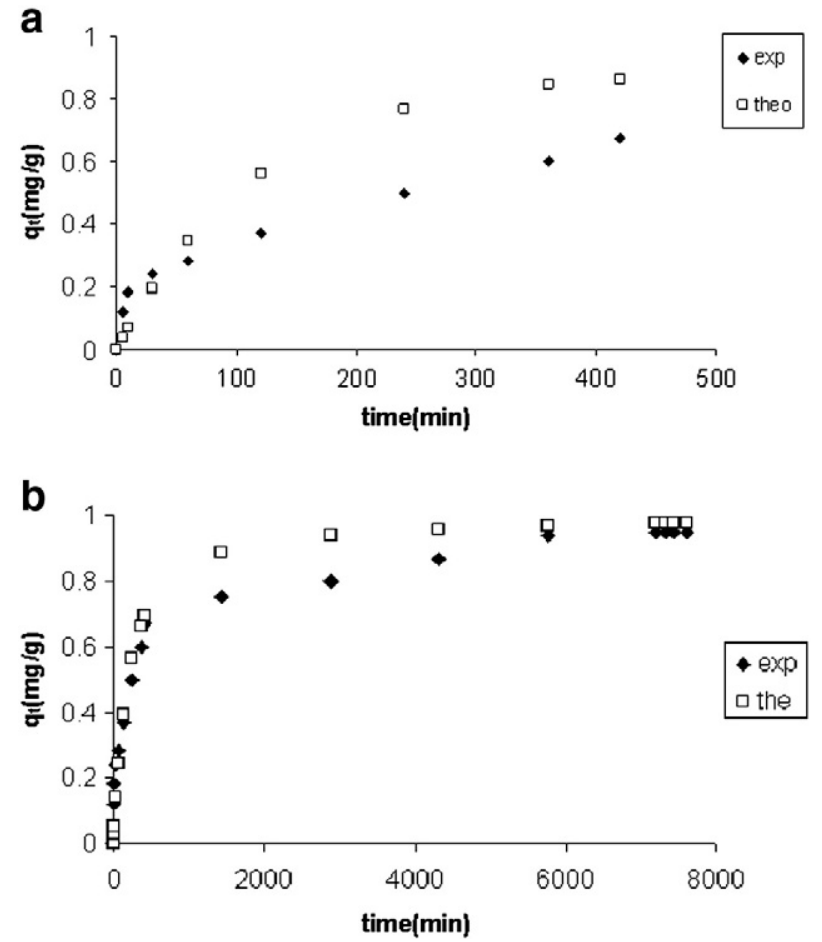

Fig. 11. Comparison of theoretical and experimental data for a) pseudo-first order model and b) pseudo second order model (experimental conditions: agitation speed $=170 \mathrm{rpm}$, initial concentration $=10 \mathrm{mg} / \mathrm{L}$, particle size $=2-0.85 \mathrm{~mm}, \mathrm{~T}=25^{\circ} \mathrm{C}, \mathrm{pH}=7$ ).

\subsection{Ion exchange}

Comparison of the equivalence of ammonium sorbed and summation of equivalences of released exchangeable cations at different initial ammonium concentrations is given in Table 6. Approximately $25-35 \%$ excess equivalence of ammonium ion is sorbed over its stoichiometric equivalence. If only ion exchange is the controlling mechanism in the sorption process, the equivalence of the major cations $\left(\mathrm{Na}^{+}, \mathrm{Mg}^{2+}, \mathrm{Ca}^{2+}\right.$ and $\left.\mathrm{K}^{+}\right)$released to the solution should be equal to those of the ammonium ion sorbed by the clinoptilolite rich mineral specimen. This indicates that both ion exchange and adsorption processes are involved in the removal of the ammonium species by the clinoptilolite rich mineral specimen. The kinetic curves of exchangeable cations $\left(\mathrm{Na}^{+}, \mathrm{Mg}^{2+}, \mathrm{Ca}^{2+}\right.$ and $\left.\mathrm{K}^{+}\right)$are presented in Fig. 12. The results indicated that the release rate and exchanged amount of $\mathrm{Mg}^{2+}$ is smaller than the others. The low value of exchange of $\mathrm{Mg}^{2+}$ might be explained by cation hydration energies and hydrated radius (Kantiranis et al., 2011). Magnesium ion only exchanged into the center of the A-channel along with its large hydration sphere. Compared to other exchangeable cations, both hydrated radius and free hydration energy value of magnesium ion are higher than those of the others. For this reason, $\mathrm{Mg}^{+2}$ ions cannot move easily out of the channels due to its considerably higher hydrated radius and free hydration energy.

\subsection{Sorption isotherms}

Equilibrium data of the experimental results were fitted to Langmuir and Freundlich model isotherms. Langmuir model assumes that sorption take place at specific homogeneous sites within the sorbents and that all sites of the sorbents are identical and energetically equivalent. The model equation is given below (Langmuir, 1918):

$\mathrm{q}_{\mathrm{e}}=\frac{\mathrm{bq}_{\mathrm{m}} \mathrm{C}_{\mathrm{e}}}{1+\mathrm{bC}_{\mathrm{e}}}$

where $\mathrm{q}_{\mathrm{e}}$ is the amount of ammonium sorbed at equilibrium $(\mathrm{mg} / \mathrm{g})$, $\mathrm{C}_{\mathrm{e}}$ is the concentration of ammonium in the solution at equilibrium $(\mathrm{mg} / \mathrm{L}), \mathrm{q}_{\mathrm{m}}$ is the maximum sorption capacity $(\mathrm{mg} / \mathrm{gr})$ and $\mathrm{b}$ is the Langmuir constant (L/mg).

The linear form of Langmuir isotherms is given as:

$\frac{C_{e}}{q_{e}}=\frac{1}{q_{m} b}+\frac{C_{e}}{q_{m}}$.

Langmuir constant (b) and maximum sorption capacity $\left(\mathrm{q}_{\mathrm{m}}\right)$ is estimated from the intercept and slope of Eq. (11).

Freundlich isotherm, which is the earliest known relationship, describes the non-ideal and reversible adsorption. The model equation is given below: (Freundlich, 1906)

$\mathrm{q}_{\mathrm{e}}=\mathrm{k}_{\mathrm{F}} \cdot \mathrm{C}_{\mathrm{e}}^{1 / \mathrm{n}}$

where $\mathrm{q}_{\mathrm{e}}$ is the amount of ammonium sorbed at equilibrium $(\mathrm{mg} / \mathrm{g})$, $C_{e}$ is the concentration of ammonium in the solution at equilibrium

\section{Table 6}

Equivalent of exchangeable cations and ammonium in clinoptilolite rich mineral specimen (experimental conditions: particle size $=2-0.85 \mathrm{~mm}, \mathrm{pH}=7.0$, initial concentration $=10 \mathrm{mg} / \mathrm{L}, \mathrm{T}=25^{\circ} \mathrm{C}$, agitation speed: $170 \mathrm{rpm}$ ).

\begin{tabular}{llll}
\hline Initial concentration $(\mathrm{mg} / \mathrm{L})$ & $\mathrm{qeq}^{\mathrm{a}}(\mathrm{meq} / \mathrm{g})$ & $\mathrm{q}_{\mathrm{eq}}{ }^{\mathrm{b}}(\mathrm{meq} / \mathrm{g})$ & \% Differences \\
\hline 10 & 0.131 & 0.100 & 24 \\
50 & 0.6 & 0.44 & 27 \\
100 & 1 & 0.65 & 35 \\
\hline
\end{tabular}

a From $\mathrm{NH}_{4}^{+}$measurements directly.

b From $\mathrm{Na}^{+}+\mathrm{Ca}^{2+}+\mathrm{K}^{+}+\mathrm{Mg}^{2+}$ measurements. 


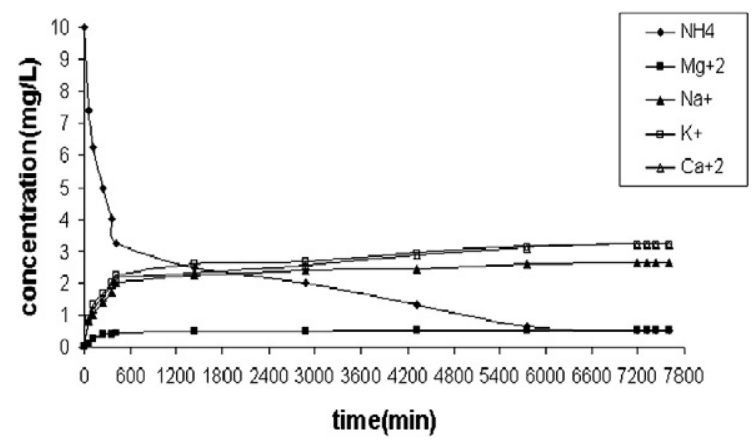

Fig. 12. The kinetic curves of exchangeable cations (experimental conditions: agitation speed $=170 \mathrm{rpm}$, initial concentration $=10 \mathrm{mg} / \mathrm{L}$, particle size $=2-0.85 \mathrm{~mm}, \mathrm{~T}=25^{\circ} \mathrm{C}$, $\mathrm{pH}=7)$.

$(\mathrm{mg} / \mathrm{L}), \mathrm{k}_{\mathrm{F}}$ is the Freundlich constant and $1 / \mathrm{n}$ is the heterogeneity factor.

The linear form of Freundlich equation is given as:

$\log \mathrm{q}_{\mathrm{e}}=\log \mathrm{k}_{\mathrm{F}}+\frac{1}{\mathrm{n}} \log \mathrm{C}_{\mathrm{e}}$

The slope and intercept of the linear plot of $\log \mathrm{q}_{\mathrm{e}}$ versus $\log \mathrm{C}_{\mathrm{e}}$ are used to determine heterogeneity factor $(1 / \mathrm{n})$ and Freundlich constant $\left(\mathrm{k}_{\mathrm{F}}\right)$, respectively.

Fig. 13 shows equilibrium isotherm data for ammonium sorption by clinoptilolite rich mineral specimen. The sorption equilibrium data fitted to Langmuir and Freundlich models with correlation coefficient values of 0.99 and 0.91 , respectively. The results implied that the equilibrium data were well represented by the Langmuir isotherm model. Isotherm model results are given in Table 7 . The maximum ammonium sorption capacity of clinoptilolite rich mineral specimen was found as $9.47 \mathrm{mg} / \mathrm{g}$. Ammonium sorption capacity values were reported in the range of $6-30 \mathrm{mg} / \mathrm{g}$ for clinoptilolite rich mineral from various origins (Englert and Rubio, 2005; Lei et al., 2008; Saltalı et al., 2007; Sarıŏlu, 2005; Sprynskyy et al., 2005; Vassileva and Voikova, 2009; Wang et al., 2007; Weatherley and Miladinovic, 2004; Widiastuti et al., 2011).

\subsection{Thermodynamic parameters}

Thermodynamic parameters such as Gibbs free energy $\left(\Delta G^{\circ}\right)$, enthalpy $\left(\Delta \mathrm{H}^{\circ}\right)$ and entropy $\left(\Delta \mathrm{S}^{\circ}\right)$ changes for the sorption of ammonium by the clinoptilolite rich mineral specimen were calculated using the following equations:

$\Delta \mathrm{G}^{0}=-\mathrm{RT} \ln \mathrm{b}_{\mathrm{m}}$

$\Delta \mathrm{G}^{0}=\Delta \mathrm{H}^{0}-\mathrm{T} \Delta \mathrm{S}^{0}$

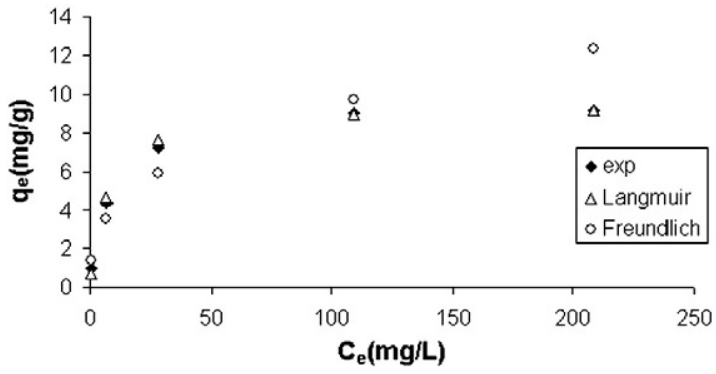

Fig. 13. Equilibrium curve for the ammonium sorption by clinoptilolite rich mineral specimen at $25^{\circ} \mathrm{C}$.
Table 7

Sorption isotherm model constants.

\begin{tabular}{llll}
\hline Models & Model constants & & \\
\hline Langmuir & $\mathrm{q}_{\max }(\mathrm{mg} / \mathrm{g})$ & $\mathrm{k}_{\mathrm{L}}(\mathrm{L} / \mathrm{mg})$ & $\mathrm{R}^{2}$ \\
& 9.47 & 0.53 & 0.99 \\
Freundlich & $\mathrm{k}_{\mathrm{F}}(\mathrm{mg} / \mathrm{g})(\mathrm{L} / \mathrm{mg})^{1 / \mathrm{n}}$ & $\mathrm{n}$ & $\mathrm{R}^{2}$ \\
& 1.79 & 2.78 & 0.91 \\
\hline
\end{tabular}

$\ln \mathrm{b}_{\mathrm{m}}=\frac{\Delta \mathrm{S}^{0}}{\mathrm{R}}-\frac{\Delta \mathrm{H}^{0}}{\mathrm{RT}}$

The values of thermodynamic parameters are given in Table 8. It is clear that the values of $\Delta \mathrm{G}^{\circ}$ are negative indicating that the ammonium sorption process is feasible and spontaneous in nature. The negative values of $\Delta \mathrm{H}^{\circ}$ indicated that the sorption process is exothermic in nature. The negative value of entropy $(\Delta S)$ showed the decreased randomness at the solid-liquid interface during the sorption of ammonium by the clinoptilolite rich mineral specimen.

\subsection{Activation energy}

The activation energy of ammonium sorption by the clinoptilolite rich mineral specimen is calculated using the Arrhenius relationship:

$\ln K=\ln A-\frac{E_{a}}{R T}$

where $\mathrm{K}$ is the rate constant, $\mathrm{A}$ is the Arrhenius constant, $\mathrm{E}_{\mathrm{a}}$ is the activation energy $(\mathrm{kJ} / \mathrm{mol}), \mathrm{R}$ is the gas constant $(8.314 \mathrm{~J} / \mathrm{mol} \mathrm{K})$ and $\mathrm{T}$ is the temperature $(\mathrm{K})$.

Activation energy of sorption process was calculated using the values of rate constant from intraparticle diffusion and pseudo second order equations. The values of activation energy $\left(E_{a}\right)$ were determined from the plot of $\ln \mathrm{K}$ versus $1 / \mathrm{T}$ and the results are given in Table 8.

The magnitude of activation energy gives an idea about the type of sorption whether it is physical or chemical. Low activation energies (5-40 kJ/mol) are characteristics for physical sorption, whereas higher activation energies $(40-800 \mathrm{~kJ} / \mathrm{mol})$ are characteristic for chemical sorption. The values of activation energy were found as 6.1 and $-12.2 \mathrm{~kJ} / \mathrm{mol}$, which is lower than $40 \mathrm{~kJ} / \mathrm{mol}$ indicating physical sorption.

\section{Conclusion}

An investigation of the effects of such experimental parameters as $\mathrm{pH}$, temperature, particle size, initial concentration and agitation speed on the ammonium uptake properties of a local clinoptilolite rich mineral specimen were presented. Initial ammonium uptake rates were significantly influenced with change in $\mathrm{pH}$, temperature, particle size, initial concentration and agitation speed. The amount of ammonium sorbed at equilibrium was found to be constant for the agitation speed and particle size conditions investigated whereas it changed with initial concentration, temperature and $\mathrm{pH}$.

Application of the sorption kinetic model results indicated that external mass transfer was predominant mechanism at the beginning of

Table 8

Thermodynamic parameters for ammonium sorption by clinoptilolite rich mineral specimen.

\begin{tabular}{llll}
\hline $\mathrm{T}[\mathrm{K}]$ & $\Delta \mathrm{G}^{\circ}(\mathrm{kJ} / \mathrm{mol})$ & $\Delta \mathrm{H}^{\circ}(\mathrm{kJ} / \mathrm{mol})$ & $\Delta \mathrm{S}^{\circ}(\mathrm{kJ} / \mathrm{molK})$ \\
\hline 298 & -15.6 & -118.4 & -0.345 \\
313 & -9.9 & & \\
\hline
\end{tabular}


the sorption process. Then, ammonium sorption process tends to be controlled by intraparticle diffusion. Intraparticle diffusion model results revealed that more than one step occurred in the sorption process. Sorption reaction model results showed that the sorption of ammonium on clinoptilolite rich mineral specimen fitted well to pseudo second order model.

The equilibrium results implied that Langmuir isotherm model were well correlated with experimental data. The thermodynamic studies indicated that the sorption is spontaneous and exothermic. The values of the activation energy indicated that the sorption of ammonium ion by the clinoptilolite rich mineral specimen is controlled by physical sorption.

As a summary, Gördes clinoptilolite rich mineral is a promising material for ammonium removal in wastewater treatment.

\section{References}

Allen, S.J., McKay, G., Khader, K.Y.H., 1989. Intraparticle diffusion of a basic dye during adsorption onto sphagnum peat. Environmental Pollution 56, 39-50.

Armenta, G.A., Iglesias, M.E.P., Ramos, R.L., 2003. Adsorption kinetic behaviour of pure $\mathrm{CO}_{2}, \mathrm{~N}_{2}$ and $\mathrm{CH}_{4}$ in natural clinoptilolite at different temperatures. Adsorption Science and Technology 21 (1), 81-91.

Atakul, S., Balköse, D., Ülkü, S., 2005. Synergistic effect of metal soaps and natural zeolite on poly(vinyl chloride) thermal stability. Journal of Vinyl Additives 11 (2), 47-56.

Can, Ö., Balköse, D., Ülkü, S., 2010. Batch and column studies on heavy metal removal using a local zeolitic tuff. Desalination 259, 17-21.

Chipera, S.J., Bish, D.L., 1995. Multi-reflection RIR and intensity normalizations for quantitative analyses: applications to feldspars and zeolites. Powder Diffraction $10,47-55$.

Demir, H., Sipahioğlu, M., Balköse, D., Ülkü, S., 2008. Effect of additives on flexible PVC foam formation. Journal of Materials Processing Technology 195 (1-3), 144-153.

Englert, A.H., Rubio, J., 2005. Characterization and environmental application of a Chilean natural zeolite. International Journal of Mineral Processing 75 (1-2), 21-29.

Erdoğan, B.C., Seyhan, A.T., Ocak, Y., Tanoğlu, M., Balköse, D., Ülkü, S., 2008. Cure kinetics of epoxy resin-natural zeolite composites. Journal of Thermal Analysis and Calorimetry 94 (3), 743-747.

Faghihian, H., Talebi, M., Pirouzi, M., 2008. Adsorption of nitrogen from natural gas by clinoptilolite. Journal of the Iranian Chemical Society 5 (3), 394-399.

Freundlich, H., 1906. Adsorption in solution. Zeitschrift für Physikalische Chemie 57, 384-410.

Huang, H., Xiao, X., Yan, B., Yang, L., 2010. Ammonium removal from aqueous solutions by using natural Chinese (Chende) zeolite as adsorbent. Journal of Hazardous Material $175,247-252$.

Ho, Y.S., McKay, G., 2000. The kinetics of sorption of divalent metal ions onto sphagnum moss peat. Water Research 34, 735-742.

Kantiranis, N., Sikalidis, K., Godelitsas, A., Squires, C., Papastergios, G., Filippidis, A. 2011. Extra-framework cation release from heulandite-type rich tuffs on exchange with $\mathrm{NH}_{4}^{+}$. Journal of Environmental Management 92 (6), 1569-1576.

Karapınar, N., 2009. Application of natural zeolite for phosphorus and ammonium removal from aqueous solutions. Journal of Hazardous Material 170, 1186-1191.

Knowlton, G.D., White, T.R., 1981. Thermal study of types of water associated with clinoptilolite. Clay and Clay Minerals 29 (5), 404-411.

Lagergren, S., 1898. About the theory of so-called adsorption of soluble substances. Kungliga Svenska Vetenskapsakademiens. Handlingar 24 (4), 1-39.
Langmuir, I., 1918. The adsorption of gases on plane surface of glass, mica, and platinum. Journal of the American Chemical Society 40, 1361-1403.

Lei, L., Li, X., Zhang, X., 2008. Ammonium removal from aqueous solutions using microwave-treated natural Chinese zeolite. Separation and Purification Technology $58,359-366$.

Malash, G.F., El-Khaiary, M.I., 2010. Piecewise linear regression: a statistical method for the analysis of experimental adsorption data by the intraparticle-diffusion models. Chemical Engineering Journal 163, 256-263.

Mathews, A.P., Weber, W.J., 1976. Effects of external mass transfer and intraparticle diffusion on adsorption rates in slurry reactors. AICHE Journal 73, 91-107.

Motsi, T., Rowson, N.A., Simmons, M.J.H., 2009. Adsorption of heavy metals from acid mine drainage by natural zeolite. International Journal of Mineral Processing 92, $42-48$.

Mumpton, F.A., 1999. La Roca Magica: uses of natural zeolites in agriculture and industry. Proceedings of the National Academy of Sciences of the United States of America 96, 3463-3470.

Özkan, F.C., Ülkü, S., 2005. The effect of $\mathrm{HCl}$ treatment on water vapor adsorption characteristic of clinoptilolite rich natural zeolites. Microporous and Mesoporous Material 77, 47-53.

Pavelic, K., Hadzija, M., Bedrica, L., Pavelic, J., Dikic, I., Katic, M., Kralj, M., Bosnar, M.H., Kapitanovic, S., Poljak-Blazi, M., Krizanac, S., Stojkovic, R., Jurin, M., Subotic, B., Colic, M., 2001. Natural zeolite clinoptilolite: new adjuvant in anticancer therapy. Journal of Molecular Medicine 78, 708-720.

Pavelic, K., Katic, M., Sverko, V., Marotti, T., Bosnjak, B., Balog, T., Stojkovic, R., Radacic, M., Colic, M., Poljak-Blazi, M., 2002. Immunostimulatory effect of natural clinoptilolite as a possible mechanism of its antimetastatic ability. Journal of Cancer Research and Clinical Oncology 128, 37-44.

Saltalı, K., Sarı, A., Aydın, M., 2007. Removal of ammonium ion from aqueous solution by natural Turkish (Yıldızeli) zeolite for environmental quality. Journal of Hazardous Materials 141, 258-263.

Sarıoglu, M., 2005. Removal of ammonium from municipal wastewater using natural Turkish (Doğantepe) zeolite. Separation and Purification Technology 41 (1), 1-11.

Savrık, S.A., Erdoğan, B.C., Balköse, D., Ülkü, S., 2010. Statistical thermal stability of PVC. Journal of Applied Polymer Science 116, 1811-1822.

Sprynskyy, M., Lebedynets, M., Terzyk, A.P., Kowalczyk, P., Namiesnik, J., Buszewski, B., 2005. Ammonium sorption from aqueous solutions by the natural zeolite Transcarpathian clinoptilolite studied under dynamic conditions. Journal of Colloid and Interface Science 284, 408-415.

Senatalar, A.E., Sirkecioğlu, A., 1995. Removal of ammonium ion from wastewaters by Bigadiç clinoptilolite. Turkish Journal of Engineering and Environmental Sciences 19, 399-405.

Top, A., Ülkü, S., 2004. Silver, zinc, and copper exchange in a Na-clinoptilolite and resulting effect on antibacterial activity. Applied Clay Science 27, 13-19.

Ülkü, S., 1984. Application of natural zeolites in water treatment. Çevre '84Umwelli'84; V. Deutch-Turkisches Symposium fur Unweltingenieurwesen.

Vassileva, P., Voikova, D., 2009. Investigation on natural and pretreated Bulgarian clinoptilolite for ammonium ions removal from aqueous solutions. Journal of Hazardous Materials 170, 948-953.

Walker, G.M., Hansen, L., Hanna, J.A., Allen, S.J., 2003. Kinetics of a reactive dye adsorption onto dolomitic sorbents. Water Research 37, 2081-2089.

Wang, Y.F., Lin, F., Pang, W.Q., 2007. Ammonium exchange in aqueous solution using Chinese natural clinoptilolite and modified zeolite. Journal of Hazardous Materials $142,160-164$.

Weatherley, L.R., Miladinovic, N.D., 2004. Comparison of the ion exchange uptake of ammonium ion onto NewZealand clinoptolite and mordenite. Water Research $38,4305-4312$.

Weber, J., Morris, J.C., 1963. Kinetics of adsorption on carbon solution. Journal of the Sanitary Engineering Division ASCE 89, 31-59.

Widiastuti, N., Wu, H., Ang, H.M., Zhang, D., 2011. Removal of ammonium from greywater using natural zeolite. Desalination 277, 15-23. 